\title{
Normal Compassion: A framework for compassionate decision making
}

\author{
Ace Simpson \\ UTS Business School \\ Centre for Management and Orgnization Studies (CMOS), \\ University of Technology, Sydney (UTS), Australia \\ 15 Broadway, Ultimo, NSW 2007, Australia \\ Email: ace.simpson@uts.edu.au \\ Phone: +61 (0) 422709853 \\ Stewart Clegg \\ UTS Business School \\ Centre for Management and Orgnization Studies (CMOS), \\ University of Technology, Sydney (UTS), Australia \\ 15 Broadway, Ultimo, NSW 2007, Australia \\ Email: stewart.clegg@uts.edu.au \\ Phone: +61 (0) 422709853

\section{Tyrone Pitsis} \\ Newcastle University Business School \\ 5 Barrack Road, Newcastle upon Tyne, NE1 4SE \\ Email: tyrone.pitsis@newcastle.ac.uk \\ Phone: +44 (0) 1912081500
}

\begin{abstract}
In this empirical paper we present a model of the dynamic legitimizing processes involved in the receiving and giving of compassion. We focus on the idea of being ‘worthy of compassion’ and show how ideas on giving and receiving compassion are highly contestable. Recognition of a worthy recipient or giver of compassion constitutes a socially recognized claim to privilege, which has ethical managerial and organizational implications. We offer a model that assists managers in fostering ethical strength in their performance by encouraging reflection on the ethical complexity involved in compassion relations. The model emphasizes the dynamics of both the givers and receivers of compassion and so
\end{abstract}


can also be used by organizations to both assess how others may view the legitimacy of their compassion relations and also to develop a positive organizational ethic of compassionate conduct.

KEY WORDS: compassion, legitimacy, positive organizational ethics, positive organizational scholarship, power 
As an ethical concept, compassion conveys a range of meanings rooted in cultural, religious, and philosophical traditions. In the Buddhist tradition, compassion is described as that which makes the heart of the good move in response to others' pain (Narada, 2006). 'Others', in the Buddhist context, is not restricted to humans but includes all sentient beings. Inherent within the Buddhist understanding is the idea that through compassion for others, one receives personal benefits of inner well-being and enlightenment (Goldstein, 1993). For most managers idealistic definitions of these sorts are probably too broad in scope, if not too confusing to be useful. In the reality of organizational life, compassion is a dynamic relational phenomenon that cannot be fully understood without accounting for power considerations of compassion as 'normal' and 'legitimate'. We question the general assumption that compassion is necessarily good and beneficial. We argue that conceptualizing compassion in terms of how it is realistically experienced has important implication to positive organizational ethics (POE).

For sociologist, Max Weber (1978), social relations gained 'legitimacy' through the processes that bestowed 'authority' That is, what is 'legitimate' is always a social construct. Institutional theorists describe legitimacy as resting upon isomorphic forces, which cause things to become more or less the same (DiMaggio \& Powell, 1983; Greenwood \& Hinings, 1996; Scott, 2008). When a person’s behavior, and a target group’s beliefs about proper action coincide with dominant normative institutionalization, action is held to be legitimate; when these things are outside the dominant institutionalized norms they are deemed as illegitimate 
(Clegg, Courpasson, \& Phillips, 2006). In this paper we explore this idea of legitimization to unpack the complexities of 'legitimate compassion' through a grounded theory approach. We summarize our findings as a model representing social conventions relating to what is perceived as legitimate and illegitimate forms of giving and receiving compassion. The model is based upon empirical data we collected in the form of readers' comments in response to two online articles, one relating to events in Australia and the other to events in the United Kingdom. These were events that one might anticipate would elicit displays of compassion for those involved. The model describes different social expectations and assumptions of the legitimate giver and the legitimate receiver of compassionate support. These legitimizing criteria are complex and dynamic, for while a person may be found to be an illegitimate recipient of compassion at the relational level, they may be found to be worthy of compassion at the organizational or societal levels and vice versa. We offer this model as a tool for managers and researchers to facilitate their assessment of the legitimacy of a person as being worthy of compassion, as well as that of a giver as worthy of providing compassionate support.

Our contribution is within the context of POE - which has sought to change the focus of organizational ethics from suppressing deviant behavior, towards promoting positive ethical practice (Stansbury \& Sonenshein, 2012). Lewis (1985, p. 382) defines business ethics as "moral rules, standards, codes, or principles which provide guidelines for right and truthful behavior in specific situations". Following Clegg, Kornberger and Rhodes’ (2007) approach to business ethics as 
practice, we respectfully disagree. Rules, standards, codes, and principles cannot function as surrogates for ethical practices but only help to frame them, often with the objective of repressing deviant unethical actions. POE are constituted by authentic leadership, supportive organizational processes, and an ethical organizational culture aligned as a living code of ethics (Verbos, Gerard, Forshey, Harding, \& Miller, 2007). We argue that POE ideas are supported through ethical choice, manifest through deliberation and reflection on the ethics of a situation in relation to the ethical dictates of right conduct. To support such deliberation in relation to compassion, we offer a model that accounts for concerns of power and legitimacy in the exercise and reception of compassion. We propose that our model of compassionate decision-making can provide a richer, more mature understanding of compassion relations. It can further be used as a framework upon which to act and make sense of compassion, mindful of its complexity and possible unintentional consequences. Consequently it can facilitate the fostering of more durable ethical strength in organizational practices. The research problem that drives our inquiry addresses how collective and individual compassion capabilities of givers and receivers of compassion are legitimated through socially constituted structures. The important point is that just being compassionate is not simply ethical and that what constitutes a 'reasonable person's' view of appropriate compassion is complex, subtle and socially situated.

\section{Constituting Legitimate Compassion}

Positive Organizational Ethics has expanded from the emerging field of Positive Organizational Scholarship (POS) (Verbos et al., 2007), where compassion has been a primary area of research and theorizing (Dutton \& Glynn, 
2008; Dutton, Lilius, \& Kanov, 2007). The related discipline of Positive Psychology has also given emphasis to the importance of compassion, focusing on compassion as individual states and traits supporting interpersonal dealings (Cassell, 2002; Neff, Rude, \& Kirkpatrick, 2007). In contrast, in Positive Organizational Behavior, compassion has not been included in the construct of Positive Psychological Capital due to the lack of evidence that it can be reliably measured and developed through organizational interventions with measurable performance impact (Luthans \& Youssef, 2004; Luthans, Youssef, \& Avolio, 2007; Youssef \& Luthans, 2012). Our treatment of compassion follows the generally more sociological orientation found in POS rather than the micro behavior orientations of Positive Psychology and Positive Organizational Behavior. POS is committed to studying that which facilitates flourishing, generativity, and strength within organizations (Berstein, 2003; Cameron \& Gaza, 2004; Dutton \& Glynn, 2008; Dutton, Glynn, \& Spreitzer, 2006).

POS researchers define organizational compassion as a three-fold process of collectively recognizing, feeling, and responding to alleviate another's suffering (Dutton, Worline, Frost, \& Lilius, 2006; Frost, 1999; Frost et al., 2006; Frost, Dutton, Worline, \& Wilson, 2000; Kanov et al., 2004). POS has a generally positive view of compassion (as evident in the special issue on compassion in the Academy of Management Review: see Rynes, Bartunek, Dutton, \& Margolis, 2012). POS research indicates that compassionate dealings with staff, particularly in times of crisis, lead to greater employee commitment, citizenship, co-worker relations, pro-social behavior, and reduce costly staff absenteeism and turnover (Dutton et al., 
2007). POS encourages managers and leaders to support the creation of compassionate environments normatively by encouraging compassionate dealings between employees, developing compassionate policies and systems for recognizing and responding to employees pain (Dutton, Frost, Worline, Lilius, \& Kanov, 2002). Nonetheless, Frost and Robinson’s (1999) concept of ‘toxic handling' indicates that POS is not blind to the harm that organizational compassion can do. Managers and leaders act as toxic handlers in organizations when they 'contagiously' absorb their employees or co-workers emotional hurt (Anandakumar, Pitsis, \& Clegg, 2007; Frost, 2003; Hatfield, Cacioppo, \& Rapson, 1993). Toxic handlers thus become vicariously vulnerable to the toxicity of the very same hurt as the people who are the objects of their sympathy.

The Oxford Dictionary (2010) defines compassion as "sympathetic pity or concern for the sufferings or misfortunes of others". Note that compassion is herein defined as synonymous with sympathy, pity, and concern. A distinction that is sometimes made between compassion and sympathy, is that whereas sympathy implies recognition and feeling for another's suffering, compassion includes an additional component of active responding to relieve the pain (Dutton, Glynn, et al., 2006). Some researchers, while acknowledging this distinction, nonetheless choose to define the terms synonymously, equating sympathy also with active responding (Kanov et al., 2004). With regard to pity, Hochschild (1983) distinguishes them by arguing that whereas 'compassion' is felt for equals, 'pity' is offered to subordinates. Clark (1987) responds that although the words compassion and pity might signify greater emotionality than 'sympathy', in her extensive research, 
respondents used the three words interchangeably in referring to people of different classes. The term empathy is distinct in that it refers to an emotional sensitivity to other's feelings but does not necessarily include the element of compassion. Nussbaum (1994) argues that some criminals, or dictators such as Adolf Hitler, could empathetically read people's emotions and manipulate them. In our study, compassion is equated with the general notions of sympathy - in terms of who is worthy to give or receive an active response of compassionate support.

Boyatzis, Smith, and Blaize (2006) emphasize the benefit of compassion relations not only to receivers in compassion relations but also the givers. When managers show compassion to employees they are replenished both neurologically and hormonally, ameliorating the negative impact of chronic stress: in other words, compassion facilitates positive embodiment. Yet, other organizational research indicates that efforts to relieve others' suffering have a potentially negative side that can cause emotional and physical harm. An example is compassion labor (Ashforth \& Humphreys, 1993; Morris \& Feldman, 1996), wherein organizational caregivers such as nurses, counselors, and airline stewards, whose job it is to smile and be kind, often exhibit the effects of compassion fatigue (Cordes \& Dougherty, 1993). Compassion is not necessarily a universal virtue. The complexities of the positive and negative outcomes of compassion relations raise questions concerning the legitimacy of compassion in different contexts.

Compassion is a social relational process that extends beyond merely noticing, feeling and responding to the pain of the other; it also involves judgments of the legitimacy of both the giving and the receiving of compassion (Clark, 1987; 
Schmitt \& Clark, 2006). Specifically, the compassion giver chooses to act in a way that they construct as compassionate. Similarly, the subject of that act of compassion may choose to recognize that action as a legitimate action for the other to initiate (as opposed, for instance, to one that is patronizing). Judgments as to the worthiness of givers and receivers within compassion relations are established through assessment of socially accepted criteria that has changed historically. For example, over the past 100 years, the number of plights recognized as legitimate causes for compassion responding has broadened from a narrow focus on injury and poverty, to include grief, mental illness, addiction, and other social concerns (Clark, 1997). Modes of compassion responding have also broadened, from a narrow focus on financial support to include psychological and substance abuse counselling. Theories explaining the emergence of a more 'humane' or 'compassionate' society relate to power. They include the rise of democracy and capitalism (De Tocqueville, 2003; Haskell, 1985; Sznaider, 1998), the lobbying of 'emotional entrepreneurs' (Clark, 1997), and ulterior motives of more efficient social control (Foucault, 1977, 1983; Nietzsche, 1998; Poovey, 1995). Within this legitimacy-power framing we broaden the conception of organizational compassion. We define organizational compassion as the ongoing individual and collective capability for concern for another's well-being, which is characterized by relational processes of assessment as to members' compassion worthiness as legitimate receiver(s) and giver(s), and responding with giving, receiving or refusal to give or receive support. Such assessments and responses implicate, produce, and reproduce power relations. 
In what follows we will use two empirical cases to consider the legitimacy of both receivers and givers of compassion. It is our intention to develop a model that might serve as a practical tool for increasing awareness of the complexities of compassion. The model we present is designed to support practical ethical reflection on compassion, where the application of religious or philosophical notions of compassion is perhaps too broad or confusing, and codes and rules too instrumental. Specific criteria for assessing the worthiness of receivers, as well as the legitimacy of givers, of compassion will be addressed. Using this model as a lens will enable us to view the dynamics of compassion as an interrelated web of agency, social relations, and social ideologies and values. We contribute to POE by providing a framework that does not assume, a priori, that compassion is necessarily positive but rather treat it as an ethical practice that requires mindful reflexivity, one aware that its positivity and negativity are context dependent.

\section{Research Context}

New media. Our field of study is on-line newspaper articles and the comments made in response to the ideas and reports in those articles. The benefits of online newspapers include speed of delivery, low cost of delivery, global reach, interactivity, and limited censorship (Reese, Rutigliano, Hyun, \& Jeong, 2007), delivered not only to a computer but also to other digital devices. These factors combine together to create a competitive displacement effect on traditional media (Dimmick, Chen, \& Li, 2004). A major appeal of Internet technologies is that they can empower users to create, develop, and distribute content easily (Hermida \& Thurman, 2008). In this new landscape users are not merely passive consumers but also active participants in the creation of media content. 
The focus in this study is on the 'comments on stories' created through user generated content (Hermida \& Thurman, 2008). The process allows users to share their views on the content of an article. Such comments are mostly submitted in a form positioned beneath the content of an article. People submitting such comments are often (but not always) required to register with the news site. One of the factors motivating large established news organizations facilitating such user generated comment is a fear of being left behind by or marginalized by other interactive user media. Additionally, there is a growing acknowledgment that some newspaper readers are well informed about certain areas and that user interaction is a means for unlocking that wealth of information. However, online news organizations also recognize the need to moderate such user generated content with pre (required registration of contributors) and post (approving messages before publishing them) screening to ensure the quality of the information and the organization's own brand (Thurman, 2008). One unobtrusive measure of the criticality of stories as they register in the collective consciousness is the amounts of commentary that these stories attract on-line; indeed, in no small way such comment legitimates these stories as critical incidents.

The proposition that commentary plays the role we have suggested was strongly supported in the response to a major turning point for user generated content in the UK: the event of the London bombings on July $7^{\text {th }}$ 2005. On this occasion the BBC and Metropolitan Police requested eyewitness images and accounts and received 22,000 emails and text messages, some 300 photos, and several video sequences on the same day as the events occurred (Torin, 2006). 
Increasingly such user-generated content is being solicited and incorporated by news organizations to supplement their professional content. The formats used for such solicitation include polls, message boards, comments on stories, reader blogs, and "have your says” and “your media” (Hermida \& Thurman, 2008; Thurman, 2008). The emergence of these opportunities for ordinary people to contribute to professionally edited publications has turned on its head the "you write, we read" dogma of traditional journalism. While the July $7^{\text {th }} 2005$ atrocities were one critical incident that served as an occasion for considerable online commentary, we wish to focus on more recent stories, especially the comments on them.

Critical incidents as occasions for commentary. The data in this study is generated from user comments to two cases, one each from the online versions of two respected newspapers The Courier Mail in Australia, and The Guardian in the UK. Case One from The Courier Mail described victims of the Queensland (Australia) floods of 2010/2011, with the 109 user comments mostly debating the validity of a receiver's compassion legitimacy. Of these 109 comments, only two were by the same person. Case Two from The Guardian described tourists from the UK and other western countries volunteering in orphanages in developing African and Asian countries, with 159 user comments by 142 people, debating the validity of a giver's compassion legitimacy. The more than 100 unsolicited user comments from each case provided a rich source of data with divergent arguments indicating the complexity of these topics. In the ethnographic tradition, we emphasize the importance of naturally occurring data in favor of 'unnatural data' gathered through formal interview techniques. We thereby make sense of text as the actors 
write it, rather than interpreting the actors' responses to questions preconceived and designed to elicit certain responses (Watson, 2011; Whittle, Mueller, \& Mangan, 2008). A benefit of this approach is that it removes the potential for researcher preconceptions influencing research participants. In each case study, only a few comments could be constituted as ‘trolling', designed to be rudely provocative. These are nonetheless important, because it is through response or refusal of these that the bounds of legitimate judgments are established. Having stated this, it should also be noted that for one of the online newspapers, comments were moderated and in some instances removed. Experimental research indicates that online forum hostility is more likely when an earlier commenter exhibits such behavior (Moor, 2007).

In case study research, cases are chosen not for statistical reasons but for theoretical reasons (Eisenhardt, 1989). In this study two specific cases were chosen because they deal with opinions on ethical assessment of receiving and giving compassionate support. Generalizations from case data are always tentative and the strength of generalizability is always a matter of judgment (Kennedy, 1979). Strength is not merely a matter of the number of observed units but also the kind and range of units as well as common attributes between the sample case and the population of interest. Research into online newspaper comments finds that they are mostly populated by local community residents making them akin to wired local communities (Rosenberry, 2010). Indeed, a positive correlation exists between awareness of community issues and the level of participation in online newspaper forums (Rosenberry, 2010; Manosevitch \& Walker, 2009). Findings 
further suggest that reader comments manifest both analytic and social processes required for public deliberation, delivering factual information and demonstrating a process of weighing alternatives by expressing positions on issues and providing supporting rationales (Manosevitch \& Walker, 2009).

Analytic strategy. We used established procedures and techniques of grounded theory building (Glaser \& Strauss, 1967) to analyze the user comments to the two online newspaper articles. We collected the data from the Internet in March 2011. We imported the data into NVivo 9 for qualitative analyzes, to highlight and categorize "nodes" comprising key themes and subthemes. The unit of analysis coded was the utterance rather than the commenter; hence there are more utterances coded than actual comments. We also took direction from the analytic strategy of membership categorization device (MCD) (Sacks, 1989, 1995), a form of analysis that involves collecting and analyzing descriptive information according to membership categories (Silverman, 2006). As examples, the words story, reading, and book relate to the category "literature", while the words student, teacher and class relate to the category of "education". From our data we initially extracted first order categories that in some cases were further summarized as second order categories. The combined categorical information was finally brought together in several theoretical dimensions forming the basis of our proposed model of conventions relating to what is perceived as legitimate giving and receiving of compassion, and other forms of illegitimate or mixed forms of giving and receiving.

\section{Case One - The Legitimate Receiver}

The Courier Mail article entitled “Queensland flood inquiry hears triple 0 
call from Donna Rice” was published on 11 April 2011 (Elsworth \& Madigen, 2011). The article reports on the proceedings of the Queensland Flood Inquiry. A Queensland Police officer was questioned about an emergency call he had taken from Donna Rice, on January 10 2011. Moments after making the call, Mrs. Rice was swept away and drowned with her son, Jordon. The authors note that the phone rang 28 times before it was answered by an officer who "yelled" at Rice, chastising her for driving in the flood waters "despite her desperate pleas for help". It further states the officer made her spell her name several times before she requested a tow truck and he told her "you ring a tow truck yourself”. The article included a link where an embedded word-for-word police transcript of the phone conversation could be downloaded. The article further reports that the Senior Constable who took the call told the inquiry that he had no recollection of the conversation.

A second desperate call made by Rice's son is also described, which the authors note rang ten times before it was answered. The officer who took the call is said to have told the boy to tell the woman next to him (Rice) to stop screaming. The boy is quoted as pleading with the officer "we are nearly drowning please hurry”. The article also notes that Rice's husband was informed that his wife was calm when she died, suggesting that the police service account was not truthful. Later, when her husband finally heard a recording of her phone call on April $18^{\text {th }}$, he found that she "was anything but calm". The remainder of the article describes other details from the inquiry regarding warning systems to alert residents of impending dangers. 
Many of the 109 reader comments that followed The Courier Mail article on the Donna Rice case debated the legitimacy of Donna Rice as a victim worthy of people's compassion. This indicates the complexity of the power plays involved in compassion dynamics. In fact, many comments expressed compassion and sympathy for "the poor old copper” [police officer] "who would have had no way of knowing” the actual situation, and was operating with "stretched resources”. The resulting debate in these comments centers predominantly around four issues relating to whether or not the victim: first, had prior-knowledge of the danger; second, was responsible for their own suffering; third, had the means to address the situation, and fourth, whether other systemic factors may have affected the situation. These issues are now addressed in more detail.

Prior knowledge of risk or danger. Whether or not Rice or the Police officer who responded to her call had prior warning of the impending danger of flooding was a major topic for debate. Some argued that Rice, along with everyone else, had prior warning, others argued that there is no way she could have had prior knowledge of the risk she was taking. A sample of comments by people who believed she acted irresponsibly in failing to heed warnings follows.

One commentator wrote that the warnings were broadcast throughout the media, arguing this fact to excuse the officer's brash tone when he responded to the emergency call. Another writer commented that Rice had deliberately ignored these warnings: "It was the lady who ignored warnings in the first place. She was told from the very start not to drive in floodwaters and she ignored that advice”. These commentators argued that Rice is an illegitimate victim and thus not a 
person worthy of compassion, due to having had prior knowledge of the impending danger.

In contrast there were those who argued that there was no way Rice could have known of the impending danger: "Mrs. Rice didn't drive through flood waters deliberately - who would know that a wall of water would flow through a main street?” Another comment of this type states that no one could have known beforehand of the impending danger: "Sorry but all the warnings in the world would in reality have fallen on deaf ears... No one knew it would be that bad, most would have battened down the hatches never expecting the carnage that happened”. Comments that Rice had no warning of the impending danger argue for Rice's legitimacy as a valid victim and a person worthy of compassion.

Personal responsibility for suffering. Many comments centered on whether Rice intentionally placed herself in the way of impending danger. Some comments suggested that Rice was responsible for her own and her son's death due to deliberately driving into a dangerous situation. One comment stated, “The wall of water that they make out happened, did happen but not in a matter of seconds but over minutes. Sufficient time to make a decision not to drive into deep water”. Another comment added:

...we all are at fault when we don't look around us to see with our eyes, to listen with our ears as to what the moments in time tell us about our surroundings. Yes, there could have been warnings, there could have been other decisions made, yet we in the end are the ones responsible for US and not some government that acts to protect itself and it's officers... 
These comments suggest that Rice is not a legitimate victim and is unworthy of compassion. Another group of comments insisted that Rice had not intentionally placed herself in harm's way and that danger came to her unexpectedly. A sample of such comments include: "In this instance ... they were not driving around through floodwater ... they were driving down the road when a wall of water approached, it only took seconds for them to be in trouble”. Another comment argued: "What people do not understand is that Mrs. Rice did not drive into the floodwaters, the floodwaters drove into them”. These comments, argue for Rice’s legitimacy as a valid victim, and thus a person worthy of compassion due to her not intentionally placing herself in danger's way.

Means to address situation. Whether or not Rice, or the Police officer, had the means to address her plight was another topic raised in many comments. Many argued that there was in fact nothing either could have done. These were circumstances beyond anyone’s control, thus making both victims of circumstance, each worthy of compassion in their own ways. One commenter attributed the events to nature’s unstoppable unbridled furry, "Stop looking for somebody to blame these unfortunate events happen and will keep happening we as humans cannot stop Mother Nature at her most furious”. Another attributed the events to fate:

It may never happen again, then again it might be ten times worse next time ... We could have an earthquake tomorrow... is everyone going to carry on about not being forewarned then, IT'S JUST FATE simple really isn't it? 
Someone else commented that only a superhuman could have saved Rice, "What could emergency services have done at that time to save her? She really needed Superman”. Another said that even if a more sympathetic officer had answered her call, there is nothing anyone could have done, "Would a seemingly more 'sympathetic' 000 operator have helped these people better in any way - NO”. These comments argue that both Rice and the officer were victims of circumstances beyond anyone’s control, making each of them worthy of compassion. Nonetheless, a majority of the comments charged that the officer's response was abusive, arrogant, and generally unacceptable, even more so because he claimed not to be able to remember the conversation. One commenter questioned:

How could Jason Wheeler forget anything that happened on that day? Sure he was not responsible for the flood or the outcome but for god's sake have the guts to recall being a jerk to a panicking drowning woman and her child.

Yet, there were many comments in support of the officer that argued that he was not responsible for the outcomes, and is himself a victim in this episode. An example of such comments follows:

For all of you having a go at the police officer for not remembering taking the call: try to imagine the sheer volume of frantic, panicked calls the operators would have taken that day, and the utter chaos in the region.

One comment supporting the officer was particularly dramatic in appealing for other readers to take compassion on the officer, "Please stop the operator 'bashing' and think about what YOU would do ... perhaps you might find some 
compassion...” All of these comments suggest that both Rice and the Police officer were victims worthy of compassion because they did not have the means to address their situation or because of the circumstances that were imposed upon them.

Other complexities. The comments indicate that considerations of systemic organizational and societal issues influence considerations of compassion legitimacy and worthiness. Comments of this nature were made particularly to evoke compassionate sympathy for the officer, who was seen as operating within limiting organizational and society contexts. These limitations, it is argued, informed and influenced his individual capacity to respond - making him a victim of the organization and society in which he operated and which assigned responsibility to him for an essentially impossible situation.

At the organizational level comments focused on poor organizational culture, and poor systems and procedures, as well as overstretched resources. With regard to organizational culture one comment stated, “This archaic patriarchal behavior is common in Qld [Queensland] and it's about time women were treated with respect, especially when in dire straits and male officers stopped misusing their power”. Others targeted overstretched resources, "Blame is being handed out to frontline staff! Anybody who struggled to provide assistance did their best with limited resources”. With regard to the operating procedures of the emergency services one comment argued, "The floods were a freak accident, it is possible though that the operator was in Perth the way things are arranged now”. Another comment stated: My only experience of calling 000 (in a medical emergency) is that the operators are inflexible and don't listen; they try to follow a script no matter 
how inappropriate for the situation, and the result is often tragic.

Another target of blame was the city and state government. Blame was cast on to the City Council both for failing to warn people and for not having emergency plans in place, "Emergency warnings are important but are totally useless unless the community has been informed beforehand of where to go and what to do when they get the call”. Others blamed the Council's poor urban planning, "I think the council is to blame but not for not warning people etc. but allowing developers to go through Toowoomba and over-develop it, dam up natural causeways for these developments, etc.” Others cast the blame higher up the chain, at the level of the State Government:

The bungling, incompetent Bligh government has been trying to buck-pass disaster management to local councils for the last 5 years or so. Every time that more incompetence and mismanagement is exposed Bligh and Co just lie their way out of it blaming others like councils who do not have and never did have the responsibility or resources to manage what is being dumped on them.

Finally, other writers blamed society’s prank callers, whose “wolf cries” had made the responding personnel suspicious of calls for help from people in genuine need:

What also needs to be looked at is the public on this day and other days. Calling 000 yelling, screaming, crying because they need a lift home, to pick up a pizza, faking a heart attack to see a friend in hospital the list goes on and on... 
The comments above, rather than casting the Police officer in the role of an indifferent or callous abuser, suggest the officer was a victim who is worthy of compassion due to not having the means to address the situations or circumstances that were imposed upon all involved. All of the above comments in this section indicate the complexity involved in determining a person's legitimacy as a person worthy of compassion. While a person's personal behavior may be seen to be the cause of their own suffering (relational practices), they might be found to be victims of poor policy or neglect in terms of organizational or social practices,. These considerations are apparent in the arguments supporting the officer who responded to Rice’s call. On the one hand, his manner was inappropriate; on the other hand it is argued that he was under-equipped and uninformed to be able to deal properly with the issues. Similarly, there are arguments that placed the blame at organizational levels, relating to the culture of the Queensland Police Department, or in relation to the overall social framing, seen in the policies of the Queensland Government. Considerations of compassion legitimacy and validity apply dynamically across relational, organizational, and societal levels as they intersect with one another.

Propositions concerning the receiver of compassion. The above findings indicate that people are less inclined to be compassionate if the sufferer is deemed to be the cause of their own misfortune, due to risky behavior or failure to pay attention to prior warnings. Thus, responsibility is indicated as an important factor in considering an agent's compassion worthiness. Assessing responsibility is a complex issue, however, as the causes of people's suffering involve a multifaceted 
mix of factors. There can be organizational as well as societal factors. A person's responsibility for suffering caused by their own doing can be outweighed by organizational or social factors outside their control. We conclude this section with a summary of our findings on conventions relating to the legitimacy of a valid recipient of compassionate care. We express these findings graphically (Figure 1); in a frequency table (Table 1) that demonstrates the frequency of latent legitimacy imagery in utterances, and in the form of two propositions, each supported by four sub-propositions.

\section{FIGURE 1 ABOUT HERE}

\section{TABLE 1 ABOUT HERE}

From the model we can develop the first proposition that people generally interpret a sufferer to be a worthy and legitimate receiver of compassion when they present (at least one of) the following characteristics (the more characteristics the stronger the case). The suffering person: 1) is not responsible for their own suffering - it is not of their own doing; 2) had no prior knowledge of any risk or danger; 3) has no means to address the situation; 4) their distress, although selfinflicted, is rooted in deeper systemic organizational or social issues.

A second proposition is that people generally interpret a sufferer as an unworthy and illegitimate recipient of compassion when they present (at least one of) the following characteristics (the more characteristics the less valid the case). The suffering person is: 1) responsible for their suffering; 2) had prior knowledge of the risk or danger; 3) has the means to the address situation; and/or 4) distress has no valid organizational or social explanation. 
The above criteria and the utterance counts in Table 1 can be used to make an assessment of the compassion worthiness of Rice and the officer. To begin, there is general agreement that neither Rice nor the officer had proper knowledge of the situation, although a few comments claimed Rice was forewarned. Yet both are held to account as being responsible for the suffering experienced, with the majority of attributions of responsibility falling on the officer (32 comments). There is a general consensus that neither had the means to address the situation with most (18) comments arguing the case of the underdog officer. People also argued that the officer's response was rooted in deeper social issues that relate to inadequate training, funding, and planning support at the levels of the local and state governments. Overall, these results could be interpreted as indicating that the majority of comments argue that Rice is certainly worthy of compassion - despite deficiencies. The officer is also worthy of compassion at a few of levels, although he must also assume some personal responsibility for the suffering experienced.

\section{Case Two - The Legitimate Giver}

The Guardian article entitled "Before you volunteer abroad, think of the harm you might do” was published on 14 November 2010 (Birrell, 2010). The article, based upon an academic paper published in Vulnerable Children and Youth Studies (Richter \& Norman, 2010), describes the negative effects of compassion. These have been identified in the literature previously, for instance in Comer and Cooper (2002), who argue that individuals whose hearts are not truly in their 'volunteer' activities will negatively affect the intended beneficiaries of these activities. In the growing 'voluntourism' industry this is particularly evident. Tour operators within this industry target the sympathies of well-off young people from 
Western countries with opportunities to volunteer as short-term caregivers at AIDS orphanages in exotic African and Asian locations. The article describes that although 'voluntourists' might have the most compassionate intentions, their impact on children is a growing cause of concern. Short-term caregivers have adverse effects on the orphaned children's emotional and psychological development. In their striving for adult attention, orphaned children are known to have little discrimination in their friendliness towards adults. Hence, bonds of attachment are quickly built with 'voluntourist' caregivers but when the voluntourist departs, also quickly broken, turning to abandonment within days or weeks. Repeated formations of attachment and abandonment upset the children's short and long-term social and emotional well-being and growth. While the departing voluntourist may have compassionate intentions, the impact of their compassion is degenerative. Further, it supports an industry that is exploitative through its commoditization and marketing of children's suffering.

Most of the 159 reader comments that followed The Guardian article on voluntourism debated the legitimacy of the voluntourist care givers, and the tourism agencies that organize voluntourism packages, as givers of compassionate support. Again, the fact that this is debated indicates the complexity of the power plays in compassion dynamics. The debate that unfolds in these comments centers predominantly around three issues relating to whether or not the givers: first, stand to profit as providers of compassionate support; second, have a legitimate relationship with the receivers; and third, whether or not the receiver gains longterm positive outcomes on account of the support they are provided. We address 
each of these issues in more detail below.

Personal profit not dominant motive in providing support. Most of the comments argued that the tourist agencies, the charities, and many of the volunteers were not worthy providers of compassionate support because they had more to gain personally from providing support than from not providing support. Hence, the support offered was seen more as self-interest rather than altruism. As one commenter wrote, “They call it charity, in fact it's enlightened self-interest”. Or in the words of another, "Charity is never about the recipient, it is all about the donor”. The self-interest people strive for in providing support can be subtly motivated by guilt or a desire to clear ones conscience or joy in the idea that others need their help. One respondent wrote, "Some people seem to enjoy the thought that others starve and thus need their help”. Some comments advocated the views that while a certain level of self-interest is inherent in all philanthropic endeavors it should not be the dominating factor, particularly when it results in ultimately harming the recipients. Comments of this kind were directed towards voluntourism operators, charities, religious organizations, and students.

Voluntourism. Most respondents spoke out against packaging charity alongside tourism. One respondent commented, "the harsh truth is that 'voluntourism' is more about the self-fulfillment of westerners than the needs of developing nations”. The following comment from a veteran voluntourist indicates the internal doubts she had about the benefit she (or the organization she was volunteering with) were providing for the local population:

I worked as a volunteer for three months in a school in the Andes earlier 
this year for a 'volunteer' organization ... I felt that the project, although five or more years old, is not integrated enough into the local community. While acknowledging its potential for abuse, however, not all comments described voluntourism as a necessarily bad thing. One author, after complaining that The Guardian article was too one sided, emphasized the need for voluntourists to be discriminating and have the right attitude actually to make a difference: “...if you are planning to go on one of these projects make sure you are willing to WORK HARD and act responsible, in order to actually benefit the local community and not simply to get the ultimate Facebook picture”.

Charities. As well as leveling critique at voluntourism operators, comments were also critical of charities that collect funds from gullible donors in the name of providing aid to needy populations. The following comment from a volunteer stationed in Cambodia is particularly critical of "fake charities" which exist only to benefit those who run the charity:

As a foreigner in Cambodia, I have seen how voluntourism can create fake charities, keep the country's people poor, promote corruption, create more performers and actors and snake oil salesmen than skilled workers, subsidize the charity with free labor and money, and create a false economy with propped up jobs, jobs with salaries so inflated by donations they could never compete or indeed, survive, in the real world...

Religious organizations. The comments above indicate that people who run tourism agencies or charities might provide aid as a means to the end of generating more personal power as money, position, and influence. Other comments raised the 
issue of religious organizations that provide aid in impoverished areas as a means towards converting new recruits and generating donations. The following comment is indicative of such a view describing "...extreme religious right wing nuts who exchange opportunity in return for affiliation”. Another comment criticized televangelists who collect money for causes and used the money to build their religious organizations in different parts of the world.

Students. Some of the harshest criticisms that were leveled against voluntourism were directed towards student volunteers. One of the major criticisms was that their motive for volunteering has "little to do with helping impoverished people”. Rather, "It's about burnishing your CV to get into the best universities and graduate employment programs”. A former student, who hadn’t volunteered before undertaking her tertiary education, wrote of the culture of competition amongst those who had been student volunteers prior to entering university:

I went to university as an untraveled, working-class girl, to find those who could not shut up about their charity escapades abroad. I'm sure they were in competition with one another; someone's work in an orphanage would be trumped by another's work in an AIDS orphanage.

Another, a tutor, spoke of first-hand experience tutoring students who volunteer only to enhance their chances of being accepted as a university entrant. These comments indicate that people are skeptical of compassionate support that is provided when the benefactor stands to gain from providing such support. Whether, in fact, such action is authentically compassionate is a moot point.

Legitimate relationship between givers and receivers. The discussion as to 
whether or not the giver had a legitimate relationship with the receivers centered on several factors. First there was concern about whether the volunteers had a recognized professional skill (such as a doctor) that they could engage to benefit the receivers. Second there was concern over whether the volunteer was prepared to make a time commitment to actually learn about the needs of the people they sought to benefit and build relationships of care. Third the respondent's discussed the virtues (or lack of virtue) in being associated with a reputable agency (government, or not-for-profit) with local connections.

Professional skills. Many respondents argued that in order to really help others in the developing world, the volunteers should seek to provide skills that are in need such as those of a doctor, teacher, or builder. One respondent articulated this idea as follows, "if they really want to make a long term difference - learn a trade or skill that is in short supply in the country they want to visit”. Similarly, another respondent offered, “I know of fully qualified, well placed doctors who take a year out to go and really help where they are needed - that is true judicious charity. Respondents also suggested that for people who didn’t have needed skills to volunteer, they could provide support by funding those who do have the required skills. In this respect one respondent argued, "if you really want to be so altruistic why not give the money you would have spent to the professionals in the field to use more productively and instead spend that year at home doing something useful there too”.

Time commitment. Genuine relationships are built and endure through the tests of time. For many respondents, a donor merely wanting to volunteer a 
professional skill was insufficient. A time commitment was also described as an additional necessary ingredient of care, required to build relationships with the local people and learn about their pains and needs. One respondent articulated this idea as follows:

If someone wants to volunteer abroad I'd suggest do it properly (min. 6 months), have a skill (which is likely not to be in supply) and make sure the organization you'll be working for has real links to local area and community (there are tons of domestic organizations looking for skilled volunteers with no ties to Western groups).

Legitimate organizations. Another way that respondents suggested people could support others, particularly people in developing countries, was by supporting a reputable organization with established longstanding relationship with local communities. Others argued that even international government aid agencies offer foreign aid to developing countries with strings attached, such that the recipient country must open up their economy to foreign investment by Western businesses. In this regard one respondent commented, "This article should not just be aimed at volunteers but businesses and international 'development' agencies too... Volunteers can mess lives up but organizations do so on a much grander scale and yet are all too easily supported here...” Nonetheless, many respondents expressed the view that donors should use discretion to discover genuine aid agencies and support only them, "If you want to help people, its best to do it through well-known and/or honest NGOs, not as part of a tour package (where they might get kickbacks from sham outfits like these fake orphanages)”. In this regard, 
another respondent shared their personal experience in working with a reputable agency that had local connections, respect for local customs, and was aware of the types of support that was needed:

VSO attempts to match requirements of the local governments for expertise with the available volunteers. It is taken as given that in every way it is a second best solution, as it would be far better if local people could do the job. The emphasis is on training possible local replacements, and it was emphasized that a good placement was one where after two years you had worked yourself out of a job, as you had helped a local person to obtain the skills to do it.

Some respondents also suggested that people who were really concerned about doing volunteer work should consider volunteering in a less glamorous environment closer to home where they can make a long-term commitment and thus gradually make a difference. One respondent questioned, “... why do they want to go abroad to 'make a difference'? There are plenty of poor or disadvantaged people in this country who may not be as photogenic”. Someone else offered, "Instead of being compelled to go to the "third world", why not cancel out all the other volunteering activities and work camps closer to home?”

Receiver's long term overall benefit. Many comments expressed concern regarding a conflict between explicit and implicit objectives. While the explicit objective of providing compassionate support is to alleviate the distress of the recipient, too often it is the implicit objective of personal agendas that often lead to the recipients of compassionate support being exploited, abused, and harmed. 
Harm can occur in the way of raised and then disappointed expectations, as well as by inducing shame that is implied by receiving charity. Harm is also caused through the creation of relationships of dependency, as well as causing suffering as a consequence of political interference.

Disappointed expectations. Some writers were particularly concerned about introducing people in developing countries to Western values or technologies that lead to disappointment within the recipient's cultural context. As an example, one respondent wrote of a benefactor who donated half a dozen radio-controlled cars to an orphanage, believing the children would get endless pleasure from them. The children’s joy was short lived, for each car used 10 batteries:

One battery cost the equivalent of a day's wages for an agricultural worker - if, indeed you could source 60 batteries locally. Result: brief excitement followed by frustration, tears and a pile of shiny but useless cars. No doubt the donor felt good but, frankly, everyone would have been better off if she'd just given them the money.

Induced sense of shame. Some respondents expressed concern that Westerners providing charity humiliate third world recipients. Even at a person-toperson level, receiving charity induces a sense of pity and shame in the recipient, "No starving man from Bolivia wants rice dolled out to him by some well-fed, well-manicured blond woman from London. Can you imagine the damage that can do to people's pride, and the resentment it would foster?”

Relationships of dependency and manipulation. Not only might receiving another's aid cause the recipient to lose their sense of personal pride and dignity 
but it can also create relationships of dependency. The dark history of how the recipients of Western aid or compassionate support have been exploited, manipulated, and harmed, by power plays in the name of Western aid was provided as one such example:

If you choose to call the West's efforts to relieve its guilt and cultivate an altruistic image while exploiting the [expletive] out of the impoverished third world "good intentions," then it would appear that the road to hell is well and good paved with them... The CIA ran a secret program to keep the Khmer Rouge armed and cashed-up. The US government ensured that it was the genocidal Khmer Rouge, and not the legitimate government, that represented Cambodia at the UN until 1993, 14 years after Vietnam brought Pol Pot's murderous regime down. That's why Cambodia remained a war zone until 1999 and is still racked with poverty today while neighboring Vietnam has been able to pick itself out of the ruins of the Yank war and become a middling Asian tiger. It's because the Yanks and their vassals are able to get away with murder and genocide that Cambodia has all those orphans that Western tourists can play with to relieve their guilt. And guess how the CIA paid for the Khmer Rouge's guns and ammo? Through the World Food Program, in the form of "aid" for "Cambodian refugees" in Thailand. That's real Western altruism for you.

Whatever the validity of the history in the above account, the fact that Western 'aid' offered to developing nations often comes with conditions requiring them to enact deregulation of their economies and open their doors to foreign 
investment by multinational enterprises is well supported by academic writings (Hodge, Coronado, \& Duarte, 2010). The overall effect of such "aid” is an overall net outflow of resources (Morgan, 2006).

Propositions concerning the giver of compassion. We conclude this case study with a summary of our findings on conventions relating to the legitimacy of a valid giver of compassionate care. We express these findings graphically (Figure 2); in data count (Table 2) that demonstrates the frequency of latent legitimacy imagery in utterances, and in the form of two propositions, each supported by three sub-propositions.

\section{FIGURE 2 ABOUT HERE}

\section{TABLE 2 ABOUT HERE}

Our analysis suggests there is great complexity involved in compassionate giving, with its potential to be implicated in all kinds of power plays. In essence we draw the following conclusions regarding legitimate compassionate giving. As a third proposition we may state that people generally interpret a person as a worthy and legitimate giver of compassionate support when they present (at least one of) the following characteristics (the more characteristics the stronger the case): 1) profit is of little consideration in providing support; 2) the giver has a legitimate relationship with receiver (either as a friend/colleague, family, an authorized professional caregiver (doctor, police, etc., government department, or reputable NGO); 3) the receiver experiences positive outcomes as a result of their support; and/or 4) the provision of support is not tied to conditions and reforms designed to give the provider greater advantage and control and make the receiver a dependent. 
A fourth proposition is that people generally interpret a person as an illegitimate giver of compassionate support when they present (at least one of) the following characteristics (the more characteristics the stronger the case): 1) there is a major opportunity for profit in providing support; 2) there is a limited relationship or no relationship at all with receiver (either as a friend/colleague, family, an authorized professional caregiver (doctor, police etc., government department, or reputable NGO); 3) the receiver experiences negative outcomes as a consequence of the support; and/or 4) the provision of support is tied to various conditions and reforms designed to give the provider greater advantage and control and make the receiver dependent.

\section{Discussion}

A multidimensional framework of compassion legitimacy. The findings of our cases illustrate our contention about the complexity of compassion being entangled with power relations: not all purported compassion relations are legitimate. More specifically, the findings provide a clearer understanding of how collective and individual compassion capabilities of givers and receivers of compassion are assessed and legitimated - the question driving our research.

Legitimacy is interwoven with power relations and so the definition of organizational compassion we presented earlier overtly assumes that compassion relations produce and reproduce power relations. The central concern of the paper is with how the legitimacy of givers and receivers is assessed in compassion relations and how responses serve to create, produce, and reproduce power relations. We expand on Clegg’s (1989: 214) ‘circuits of power’ model to provide our analytic framework. The model likens power to electricity that flows through 
three distinct interacting circuits (Backhouse, Hsu, \& Silva, 2006). In the past, power relations have often been thought of as structural, as dimensions of everdeeper analysis (Lukes, 2005). The model eschews this imagery and instead suggests that power relations flow through distinct circuits. We will analyze the data from our two cases by classifying it within the three power 'circuits'. The first of these deals with explicit power episodes, where overt social actions are launched. Here an agency A attempts to do something to an agency B that B may resist. The episodic circuit is constituted at the micro-level through irregular exercises of power as agents try to assert their will and resist such impositions, as they address feelings, communication, conflict, and resistance in day-to-day social relations. The outcomes of the episodic circuit are both positive and negative. The second conduit or circuit of power is concerned with the habitual dispositions that are embedded in the dispositional-level rules and socially constructed meaning and membership that frame member relations and legitimate knowing in specific settings. These are developed through practices that crucially involve the normative evaluation of a collective. Within this level, normative patterns of behavior unfold, and the power exerted is the power that lies in continuing or contesting "business as usual". The facilitative circuit of power is constituted by macro-level structures, institutional rights and duties as well as the technologies of power embedded in socio-material structures that institutionalize disciplinary frameworks as ways of sense making. Such structures empower and disempower and punish and reward expressions of agency in the episodic circuit as well as inhibit or generate norms in a practicing collective. The facilitative circuit is 
changeable by agency in the episodic circuit and by the collective constitution of norms in the dispositional circuit, as well as by the impact of random events and unanticipated contingencies.

The three circuits interact, and are constituted by, and constitute each other as “obligatory passage points”. These are the conduits through which traffic through the circuits must pass, given the current fixity of social relations, channels that effectively empower some agencies as they disempower others in terms of fixed and extant social relations. Obligatory passage points are also the places where power shifts can be enacted and observed.

Using the power framework allows us to bring together the findings of both Case One and Case Two into a Multidimensional Framework of Compassion Legitimacy Dynamics (Figure 3). The assessment criteria for legitimate compassion receiving are depicted on the top left side of the model, while the criteria for illegitimate receiving on the model's bottom left side. Conversely, the assessment criteria for legitimate giving of compassionate support are depicted on the model's top right side, while the criteria for illegitimate giving is depicted on the models bottom right. In the middle of the model are three circles indicating three circuits of episodic, dispositional, and facilitative power. In these circuits positive and negative compassion dynamics of legitimacy and illegitimacy are seen to flow, converge, and diverge, indicating the power complexities involved in compassion legitimacy determinations. On the right and left side of these circles are arrows indicating that the legitimacy criteria described at the top and bottom 
sides of the model will tend to blend and mix - with considerations of both legitimacy and illegitimacy represented in almost each and every case study.

\section{FIGURE 3 ABOUT HERE}

Compassion legitimacy. Compassion is represented in this model as having potentially both positive and negative dynamics. Where the motive of compassion is present the results may, nonetheless, be disastrous for those who are the subjects and objects of such compassion. Clegg et al.'s (2006) account of the policies that produced the ‘stolen generation’ of half-caste Australian aboriginal children taken from their mothers and institutionalized elsewhere is a case in point. The action was done with a compassionate motive in terms of the social context in which it was enacted; the results, however, have been likened to cultural genocide. Our case data gave many such examples. One involved compassionate donation of a battery operated toy cars for children, which quickly led to disappointment, as the batteries were too costly for these people to replace. Another was the concern that receiving food dished out by western foreign aid workers can induce a sense of shame and loss of dignity for people in third world countries.

Issues of legitimacy and power are always complex, mixed, and never entirely pure. According to Habermas (1976) élites attempt to manipulate public perception and to achieve legitimization for favored ideologies is a form of covert power. Similarly, this study has demonstrated how people try to manipulate other's perceptions of themselves (or their organizations) as legitimate receivers or givers of compassionate support. Individuals, organizations, professions, and leaders seek legitimacy as a means of gaining apparently authoritative power (Clegg et al., 
2006). In a socially responsible society, or at least one that prides itself on being such, a legitimate victim commands the power to receive other's compassion through special favors, exceptions, and rewards. Such favors may include financial compensation, honors, and personal attention from the media and high placed dignitaries. Due to the power commanded by the recipient of compassion, their 'right' to compassion must be established based on their status as a valid or legitimate victim. Not all people who suffer are innocent: suffering may be self inflicted and thus viewed as not worthy of compassion. In some instances, a sufferer may be source of moral outrage and the target of socially legitimized abuse.

Power plays. The episodic circuit represents irregular micro-level exercises of power in compassion relations. Givers of compassion can enact power over receivers by providing compassionate support to manipulate them into positions of indebtedness or intimacy (Clark, 1987, 1997; Schmitt \& Clark, 2006). Such providing of compassionate support can further belittle and patronize the receiver by highlighting their problems and limitations. Giving compassion to belittle the power of a person in a high position such as a mean boss, by feeling sorry for them rather than feeling anger, hatred, or fear towards them. Refusing compassionate support where the would-be receiver minimizes the giver's social status, and reinforces their social standing is another form of power play. Even when a receiver accepts compassionate support they can still raise their own social status through public displays of gratitude, which indicate the receiver's connections with powerful persons. 
In the findings of this paper examples of power-compassion episodes include the interaction between Rice who pleaded for help, and the officer who refused support - or maybe (from his perspective) provided support through a tough-love reprimand about personal responsibility. The dispositional circuit is constituted of socially constructed rules and meaning that frame member relations and legitimate knowing. Examples of normative ways of displaying compassion at the dispositional circuit include the activities of voluntourism, which is often enacted in order to enhance the voluntourist's résumé, and the established activities of different charity groups and religious organizations operating in the name of service to the poor while in fact pursuing ulterior purposes. The facilitative circuit is constituted of macro-level rights, duties, facilitating and inhibiting technologies, and constituted by institutionalized and disciplinary frameworks. In this study, examples of compassion enhancement or inhibition at the facilitative level are found in the regional and state governmental policies that effect the capacity of members of the Queensland Police Force and other government agencies to perform their responsibilities in providing compassionate support. Such policies can relate to the adequate funding and administration of government agencies, including decisions to centralize emergency responding at a state level or place that responsibility on local agencies that may or may not be equipped to deal with such non-routine circumstances.

Nodal transitions occur as the 'obligatory passage points' where the three circuits interact, constitute, and are constituted by each other. Analyzing compassion as power relations through these circuits allows us to see how micro, 
meso, and macro levels of compassion legitimacy are connected to and influence each other. A relational dependency exists between levels that are necessary to understand and analyze the implications of compassion in organization. Thus, assessing the legitimacy of a giver or receiver is a complex issue, as the causes of peoples suffering involve a multifaceted mix of factors. These can entail personal relational factors (episodic circuit) organizational factors (dispositional circuit) as well as societal factors (facilitative circuit). As such, a person's responsibility for suffering caused by their own doing might be outweighed by other organizational or society factors outside of their control. Whereas a person may look unworthy as a recipient of compassion (as in the case of the officer who took Rice's call), by crossing to a different circuit via these nodal transitions, innocence can be argued, and power regained as a victim of the system.

The legitimate receiver reanalyzed. The findings of this article provide many examples of how these circuits intersect. Consider the officer who responded to Rice's call in Case One. At the episodic level his responding behavior was inappropriate, yet some argued that he was nonetheless a victim due to dispositional level considerations of being under-equipped and uninformed to properly deal with the issues, or that the culture of the Queensland Police Department was to blame. Others held him as a legitimate victim, due to deeper systemic facilitative level issues, issues that were reflected in the policies of the Queensland Government.

The legitimate giver reanalyzed. In terms of the legitimate giver of compassion, what can appear to be compassion at the episodic level of 
interpersonal relations, might in fact be a form of manipulation by managers who use compassion as a front at the organizational level, or by a government who use compassion as a front for large-scale political manipulation. Examples of such considerations were found in the comments of our second case study. Respondents described the corrupt practices of 'sham charities', as well as religious organizations that provide charity support (episodic) in exchange for people’s conversion into their religious organization (dispositional, facilitative). They also narrated a history of political interference by the US government in Vietnam and Cambodia (dispositional, facilitative) - funded under the guise of a World Food aid program (episodic). The providing of Western aid (episodic) in exchange for investment opportunities (dispositional, facilitative) that end up draining third world economies is another example of such dynamics.

The dynamic arrows pointing to each side of the power circuits in the model indicates the interdependence of the circuits. They also indicate that compassion is an ever emerging and ongoing dynamic power process - as stated in our definition. In taking this approach we view compassion as more than concern for others suffering, it is additionally composed of distinct practices of social relations such as assessment that informs responses of giving, receiving, or refusing. Our compassion dynamics framework provides some insight into how these power dynamics work and is therefore a valuable tool for guiding decisions and policies as they relate to the giving and receiving of compassionate support.

\section{Conclusions}

In this paper we have questioned the default assumption that organizational displays of compassion are necessarily positive and beneficial. We have presented 
a more complex view of compassion as a practice wherein one needs to consider the voices of givers and receivers in compassion relations. Such consideration reveals power inequalities with outcomes that are sometimes beneficial and at other times not. We have supported these views with empirical data derived from the comments of the readers of two cases published by two leading online newspapers, one in Australia the other from the UK. Our data indicate that not all purported compassion relations are legitimate. We have used this data to construct a model of compassionate decision-making for understanding the complexity of legitimate and illegitimate compassion relations. The model presents the different social expectations and assumptions of the legitimate giver and the legitimate receiver of compassionate support. These are distilled and presented as four propositions related to both the receiver and giver of compassion.

The findings of this study are limited by the context of online social media comments (Hermida \& Thurman, 2008; Thurman, 2008), within a Western cultural context. It is also possible that the opportunity to comment anonymously behind an alias allows people to share views that they might otherwise not reveal in a face-toface context. The opportunity to comment anonymously might also provide an impetus to trolling (Bowman, 2011), a possible advantage for research access to unfiltered candid perspectives. It is also possible, however, that some comments will just be made for the sake of harassing or disturbing others in the forum and are thus not representative of actual opinions. While there were a small number of comments that could be judged to inflame opinion, people commenting online sought to moderate extreme comments. More importantly, where behavior was 
moderated online, people were more likely to adhere to norms set by previous commentators, irrespective of whether the person making the comments was anonymous or required to provide their name and location (see Moor, Heuvelman, \& Verleur, 2010). Although people who comment do have public anonymity in such forums, they are required to register before they can leave comments, and the newspaper mediates the forums and the online moderator will delete or edit comments if they seek to make extremely inflammatory comments, thus establishing norms that can restrict extreme comments. Amongst our data from the Guardian article there were two comments that had been removed with the following message: “This comment was removed by a moderator because it didn’t abide by our community standards. Replies may also be deleted”. Thus, people are not entirely free to comment as they wish; they are held accountable for offensive and hateful comments. Aside from that, even such deliberately provocative comments are valuable because they bring additional perspectives to the debate on the legitimacy of givers and receivers in compassion relations.

Another limitation to the study is that some other individual factors may account for the patterns in the responses coded. For example, peoples' differing operational philosophy may account for how they see who and why someone might be worthy of concern. If they are pragmatic, then the efficacy argument works well. But if the reader is more humanitarian, they might offer different rationales and criteria for legitimacy and normalcy.

Future research could seek to overcome the boundaries of the limitations imposed by the context of this study by testing the compassion legitimacy and 
worthiness model in a variety of other contexts - including face to face, and especially in different cultural contexts. For example, several vignettes could be composed based upon the various compassion legitimacy criteria and respondents asked to rank the compassion worthiness of the receivers and givers in these vignettes. Similarly, the model could be tested statistically by developing a compassion legitimacy and worthiness scale where respondents rank compassion legitimacy and worthiness criteria as described in this study. Such a scale would need to be correlated against other validated scales in order to determine response norms in a large population of respondents. The development of these research projects would facilitate deeper understandings of social conventions relating to the legitimate giving and receiving of compassion. Increasingly, such research is important, because with increased scrutiny and demands for ethical integrity demanded of contemporary managers, reflection on the ethical complexity involved in the showing or withholding of compassionate support is necessary.

Our purpose in conducting this research has not been to dismiss the positive benefits of compassion as described in spiritual or theological texts or the findings of POS research. Rather our point is to bring more subtlety to the discussion through articulating other nuances that, as our research reveals, are present in the popular consciousness. The model we propose provides practical value for advancing the POE objective of promoting a living code of ethics (Verbos et al., 2007), as it provides a framework for systematic ethical reflection, sensitizing managers' discrimination in the expression of compassion within organizations. Managers can use this model to develop an organizational code of compassionate 
conduct that considers specific criteria for assessing the worthiness of the receiver, as well as assess how others may view their legitimacy as a giver worthy to provide compassionate support. This model can be applied to improve the design of policies and decisions that embody positive organizational ethics in a range of contexts and situations where ethical decision making is central to organizational life: these can include organizational and managerial responses to mental and physical illness and disability of staff and customers; maternal and paternal leave, bereavement, and other family related phenomena; the discipline and punishment of staff, as well as a range of other issues pertaining to the expression of compassion.

Using this model as a lens will enable managers to view the dynamics of compassion as an interrelated web of agency, social relations, and social ideologies and values. Consequently, they will make 'better' decisions by reflecting on the frameworks upon which they base their actions in relation to compassion that leads to a questioning of idiographic psychological value judgments. In this conceptualization, compassion is embedded within relations of power conceived not as an individual possession or title but as the quality of the relationships between individuals or structures (Clegg et al., 2006). Managers using this framework will be able to build power in a positive/ethical manner by designing organization relations and encouraging organizational practices that are founded upon a respectful appreciation of the other. Compassionate action is always a social relation and a social action that involves another - our intention is to ensure that judgments of the otherness of others are given due attention and consideration. 


\section{References}

Anandakumar, A., Pitsis, T. S., \& Clegg, S. R. (2007). Everybody hurts sometimes: The language of emotionality and the dysfunctional organization. In J. Langan-Fox, C. L. Cooper \& R. J. Klimoski (Eds.), Research Companion To The Dysfunctional Workplace Management Challenges and Symptoms (pp. 187-215). Cheltenham: Edward Elgar Publishing Ltd.

Ashforth, B. E., \& Humphreys, M. (1993). Emotional labor in service roles: The influence of identity. Academy of Management Review, 18(1), 88-115.

Backhouse, J., Hsu, C. W., \& Silva, L. (2006). Circuits of power in creating de jure standards: shaping an international information systems security standard. Management information systems quarterly, 30(1), 413.

Berstein, S. D. (2003). Positive organizational scholarship: Meet the movement. An interview with Kim Cameron, Jane Dutton, and Robert Quin. Journal of Management Inquiry, 12(3), 266-271.

Birrell, I. (2010). Before you pay to volunteer abroad, think of the harm you might do. The Guardian, 14 November. Retrieved from http://www.guardian.co.uk/commentisfree/2010/nov/14/orphanscambodia-aids-holidays-madonna

Bowman, J. (2011). Rise of the trolls. New Criterion, 29(5), 63-67.

Boyatzis, R. E., Smith, M. L., \& Blaize, N. (2006). Developing sustainable leaders through coaching and compassion. The Academy of Management Learning and Education ARCHIVE, 5(1), 8-24.

Cameron, K. S., \& Gaza, A. (2004). Introduction: Contributions to the discipline of positive organizational scholarship. American Behavioral Scientist, 47(6), 731-739.

Cassell, E. J. (2002). Compassion. In C. R. Snyder \& S. J. Lopez (Eds.), Handbook of positive psychology. New York, NY: Oxford University Press.

Clark, C. (1987). Sympathy biography and sympathy margin. American Journal of Sociology, 93(2), 290-321.

Clark, C. (1997). Misery and company: Sympathy in everyday life. Chicago, IL: University of Chicago Press.

Clegg, S. R. (2006). Why is organization theory so ignorant? The neglect of total institutions. Journal of Management Inquiry, 15(4), 426-430.

Clegg, S. R., Courpasson, D., \& Phillips, N. (2006). Power and organizations. London, UK: Sage.

Clegg, S. R., Kornberger, M., \& Rhodes, C. (2007). Business ethics as practice. British Journal of Management, 18(2), 107-122.

Comer, D. R., \& Cooper, E. A. (2002). A model of employees' responses to corporate "volunteerism". Research in Ethical Issues in Organizations, 4, 145-168.

Cordes, C. L., \& Dougherty, T. W. (1993). A review and an integration of research on job burnout. Academy of Management Review, 18(4), 621656. 
De Tocqueville, A. (2003). Democracy in America (G. E. Baven, Trans.). London, UK: Penguin.

DiMaggio, P. J., \& Powell, W. W. (1983). The iron cage revisited: Institutional isomorphism and collective rationality in organizational fields. American sociological review, 48(2), 147-160.

Dimmick, J., Chen, Y., \& Li, Z. (2004). Competition between the Internet and traditional news media: The gratification-opportunities niche dimension. Journal of Media Economics, 17(1), 19-33.

Dutton, J. E., Frost, P., Worline, M. C., Lilius, J. M., \& Kanov, J. M. (2002). Leading in times of trauma. Harvard Business Review, 80(1), 54-61.

Dutton, J. E., \& Glynn, M. A. (2008). Positive organizational scholarship. In C. Cooper \& J. Barling (Eds.), Handbook of Organizational Behavior. Thousand Oaks, CA: Sage.

Dutton, J. E., Glynn, M. A., \& Spreitzer, G. M. (2006). Positive organizational scholarship. In J. Greenhaus \& G. Callanan (Eds.), Encyclopedia of Career Development (pp. 641-644). Thousand Oaks, CA: Sage.

Dutton, J. E., Lilius, J. M., \& Kanov, J. M. (2007). The transformative potential of compassion at work. In S. K. Piderit, R. E. Fry \& D. L. Cooperrider (Eds.), Handbook of transformative cooperation: New designs and dynamics (pp. 107-124). Stanford, CA: Standford University Press.

Dutton, J. E., Worline, M. C., Frost, P. J., \& Lilius, J. (2006). Explaining compassion organizing. Administrative Science Quarterly, 51(1), 59-96.

Eisenhardt, K. M. (1989). Building theories from case study research. Academy of Management Review, 532-550.

Elsworth, S., \& Madigen, M. (2011). Queensland flood inquiry hears tripple 0 call from Donna Rice. The Courier Mail, 19 April. Retrieved from http://www.couriermail.com.au/news/donna-rice-told-off-by-triple-0operator-for-driving-through-flood/story-e6freon6-1226041207841

Foucault, M. (1977). Discipline and punish: The birth of the prison (A. Sheridan, Trans.). New York, NY: Pantheon.

Foucault, M. (1983). On the genealogy of ethics. In H. Dreyfus \& P. Rabinow (Eds.), Michel Foucault: Beyond structuralism and hermeneutic. Chicago, IL: University of Chicago Press.

Frost, P. J. (1999). Why compassion counts. Journal of Management Inquiry, $8(2), 127-133$.

Frost, P. J. (2003). Toxic emotions at work. Boston: Harvard Business School Press.

Frost, P. J., Dutton, J. E., Maitlis, S., Lilius, J. M., Kanov, J. M., \& Worline, M. C. (2006). Seeing organizations differently: Three lenses on compassion. In S. R. Clegg, C. Hardy, T. B. Lawrence \& W. R. Nord (Eds.), The Sage handbook of organization studies (pp. 843-866). London, UK: Sage.

Frost, P. J., Dutton, J. E., Worline, M. C., \& Wilson, A. (2000). Narratives of compassion in organizations. In S. Fineman (Ed.), Emotions in organizations (pp. 25-45). London, UK: Sage Publications.

Frost, P. J., \& Robinson, S. (1999). The toxic handler: organizational hero--and casualty. Harvard Business Review, 77(4), 96-106. 
Glaser, B. G., \& Strauss, A. L. (1967). The discovery of grounded theory: Strategies for qualitative research. Chicago: Aldine Publishing Company.

Goldstein, J. (1993). Insight meditation: The practice of freedom. Boston, MA: Shambhala.

Greenwood, R., \& Hinings, C. R. (1996). Understanding radical organizational change: Bringing together the old and the new institutionalism. Academy of Management Review, 1022-1054.

Habermas, J. (1976). Legitimation crisis (T. McCarthy, Trans.): Heinemann London.

Haskell, T. L. (1985). Capitalism and the origins of the humanitarian sensibility, Part 1. The American Historical Review, 90(2), 339-361.

Hatfield, E., Cacioppo, J. T., \& Rapson, R. L. (1993). Emotional contagion. Current Directions in Psychological Science, 2(3), 96-100.

Hermida, A., \& Thurman, N. J. (2008). A clash of cultures: The integration of user-generated content within professional journalistic frameworks at British newspaper websites. Journalism Practice, 2(3), 343-356.

Hochschild, A. R. (1983). The managed heart: Commercialization of human feeling. Berkeley, Ca: University of California Press.

Hodge, B., Coronado, G., \& Duarte, F. (2010). Chaos theory and the larrikin principle. Frederiksberg, Denmark: CBS Press.

Kanov, J. M., Maltlis, S., Worline, M. C., Dutton, J. E., Frost, P. J., \& Lilius, J. M. (2004). Compassion in organizational life. American Behavioral Scientist, 47(6), 808-827.

Kennedy, M. M. (1979). Generalizing from single case studies. Evaluation Review, 3(4), 661-678.

Lewis, P. V. (1985). Defining 'business ethics': Like nailing jello to a wall. Journal of Business Ethics, 4(5), 377-383.

Lukes, S. (2005). Power and the battle for hearts and minds. Millennium: Journal of International Studies, 33(3), 477-493.

Luthans, F., \& Youssef, C. (2004). Human, Social, and Now Positive Psychological Capital Management: Investing in People for Competitive Advantage. Organisational Dynamics, 33(2), 143-160.

Luthans, F., Youssef, C. M., \& Avolio, B. J. (2007). Psychological capital: Developing the human competitive edge. New York, NY: Oxford University Press, USA.

Manosevitch, E., \& Walker, D. (2009). Reader comments to online opinion journalism: a space of public deliberation.

Moor, P. J. (2007). Conforming to the flaming norm in the online commenting situation.

Moor, P. J., Heuvelman, A., \& Verleur, R. (2010). Flaming on youtube. Computers in Human Behavior, 26(6), 1536-1546.

Morgan, G. (2006). The ugly face: Organizations as instruments of domination Images of organization (pp. 291-333). London, UK: Sage.

Morris, J. A., \& Feldman, D. C. (1996). The dimensions, antecedents, and consequences of emotional labor. Academy of Management Review, 21(1), 986-1010. 
Narada. (2006). The Buddha and his teachings. Mumbai, India: Jaico.

Neff, K. D., Rude, S. S., \& Kirkpatrick, K. L. (2007). An examination of selfcompassion in relation to positive psychological functioning and personality traits. Journal of Research in Personality, 41(4), 908-916.

Nietzsche, F. (1998). On the genealogy of morals (D. Smith, Trans.). New York, NY: Oxford University Press.

Nussbaum. (1994). Pity and mercy: Nietzsche's stoicism. In Schacht (Ed.), Nietzsche, Genealogy, Morality: University of Canlifornia Press.

Oxford Dictionary of English. (2010). Oxford Reference Online Premium: Oxford University Press.

Poovey, M. (1995). Making a social body: British cultural formation, 1830-1864: University of Chicago Press.

Reese, S. D., Rutigliano, L., Hyun, K., \& Jeong, J. (2007). Mapping the blogosphere. Journalism \& Mass Communication, 8(3), 235.

Richter, L., \& Norman, A. (2010). AIDS orphan tourism: A threat to young children in residential care. Vulnerable Children and Youth Studies, 5(3), 217-229.

Rosenberry, J. (2010). Virtual community support for offline communities through online newspaper message forums. Journalism \& Mass Communication Quarterly, 87(1), 154-169.

Rynes, S., Bartunek, J., Dutton, J., \& Margolis, J. (2012). Care and compassion through an organizational lens: Opening up new possibilities. Academy of Management Review, Published online ahead of print.

Sacks, H. (1989). Lecture Six: The MIR Membership Categorization Device. Human Studies, 12(3), 271-281.

Sacks, H. (1995). Lectures on conversation: Wiley-Blackwell.

Schmitt, C., \& Clark, C. (2006). Sympathy. Handbook of the Sociology of Emotions, 467-492.

Scott, W. R. (2008). Approaching adulthood: The maturing of institutional theory. Theory and Society, 37(5), 427-442.

Silverman, D. (2006). Interpreting qualitative data: Methods for analyzing talk, text, and interaction: Sage Publications Ltd.

Stansbury, J. M., \& Sonenshein, S. (2012). Positive business ethics: Grounding and elaborating a theory of good works. In K. S. Cameron \& G. Spreitzer (Eds.), The Oxford Handbook of Positive Organizational Scholarship (pp. 340-352). New York, NY: Oxford University Press.

Sznaider, N. (1998). The sociology of compassion: A study in the sociology of morals. Journal for Cultural Research, 2(1), 117-139.

Thurman, N. J. (2008). Forums for citizen journalists? Adoption of user generated content initiatives by online news media. New Media \& Society, 10(1), 139-157.

Torin, D. (2006). How $7 / 7$ 'democratised' the media. BBC News, 4 July. Retrieved from http://news.bbc.co.uk/2/hi/uk news/5142702.stm

Verbos, A. K., Gerard, J. A., Forshey, P. R., Harding, C. S., \& Miller, J. S. (2007). The positive ethical organization: Enacting a living code of ethics and ethical organizational identity. Journal of Business Ethics, 76(1), 17-33. 
Watson, T. J. (2011). Ethnography, reality, and truth: the vital need for studies of 'how things work' in organizations and management. Journal of Management Studies, 48(1), 202-217.

Weber, M. (1978). Economy and society: an outline of interpretive sociology. Berkley, CA: University of California Press.

Whittle, A., Mueller, F., \& Mangan, A. (2008). In search of subtlety: Discursive devices and rhetorical competence. Management Communication Quarterly, 22(1), 99-122.

Youssef, C., \& Luthans, F. (2012). Psychological capital: Meaning, findings and future directions. In K. S. Cameron \& G. Spreitzer (Eds.), The Oxford handbook of positive organizational scholarship (pp. 17-27). Oxford, UK: Oxford University Press. 


\section{Figure 1: Receiver legitimacy and compassion worthiness}

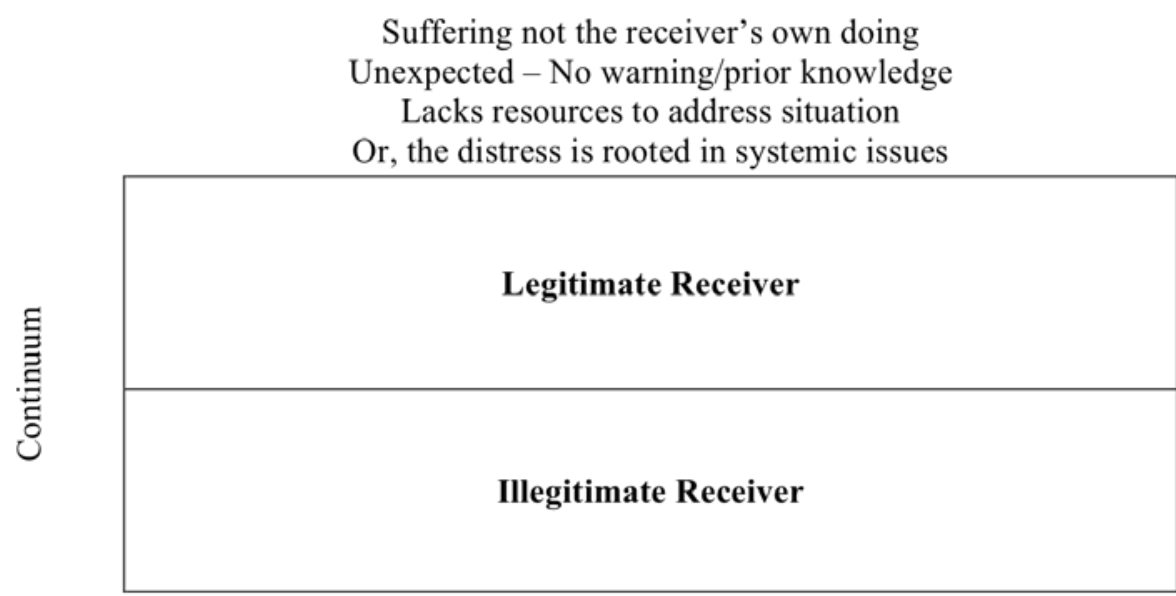

Suffering the receiver's own doing

Did not heed prior warning/knowledge

Has resources to address situation

Distress is not rooted in systemic issues

\section{Figure 2: Considerations of (il)legitimacy as a giver of compassion}

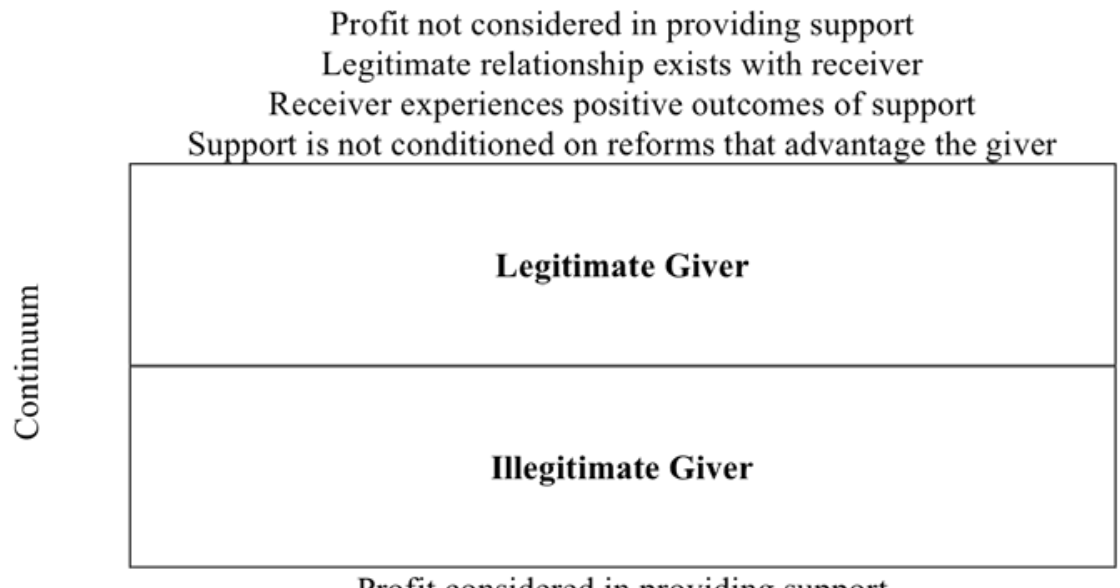

Profit not considered in providing support

Legitimate relationship exists with receiver

Receiver experiences positive outcomes of support

Profit considered in providing support

No legitimate relationship exists with receiver

Receiver doesn't experience positive outcomes of support

Support is conditioned on reforms that advantage the giver 
Figure 3: Compassion legitimacy and worthiness model 


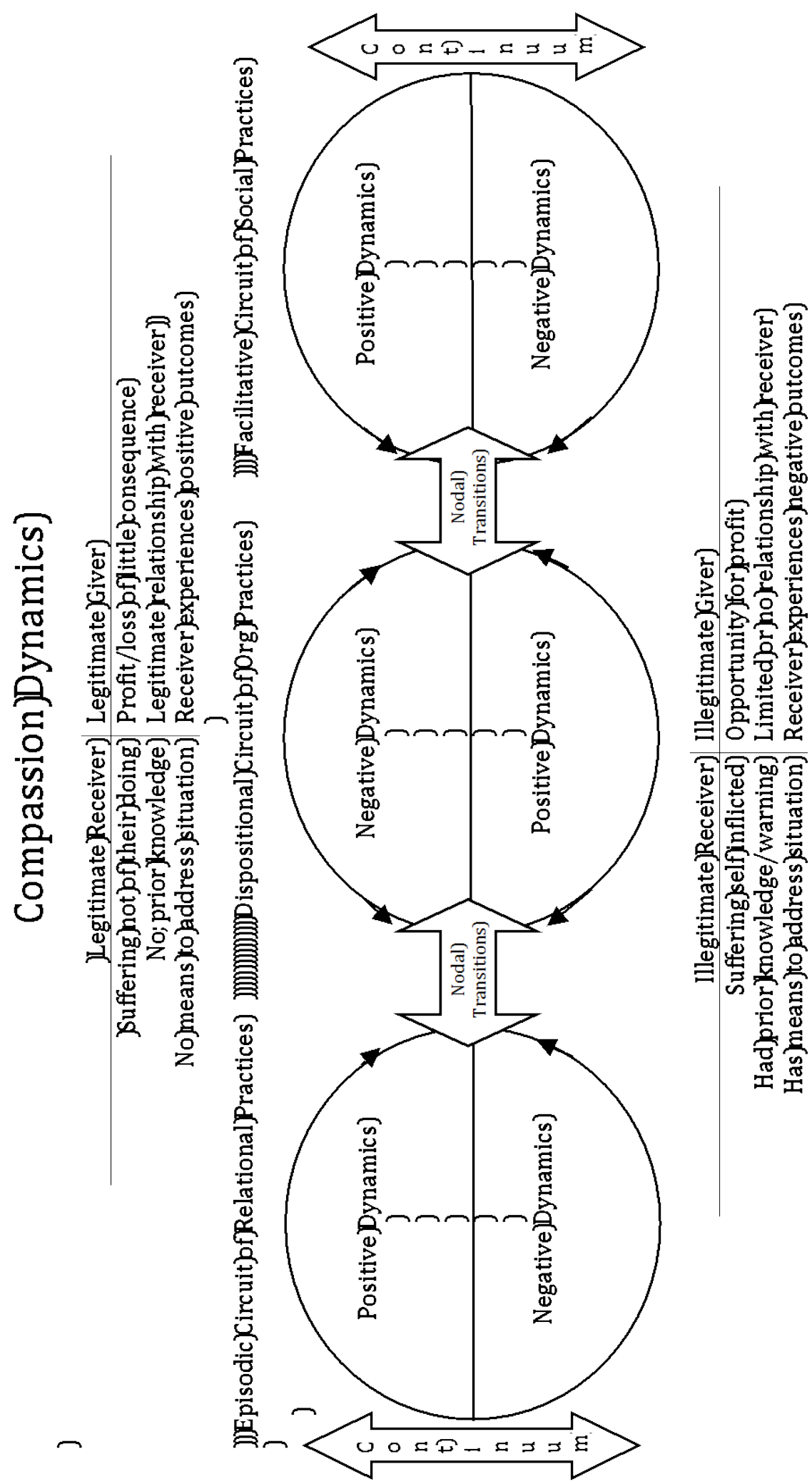


Table 1: Latent imagery of (il)legitimacy of receiver in utterances

\section{Legitimate Receiver}

Theme
Sub category Number of utterances

No prior knowledge of risk
No personal responsibility for suffering

No means to address situation

Other complexities and systemic issues

$\begin{array}{rr}\text { Rice } & 6 \\ \text { Officer } & 5 \\ \text { General } & \underline{8} \\ & \text { Total } 19\end{array}$

$\begin{array}{rc}\text { Rice } & 3 \\ \text { Officer } & 7 \\ \text { General } & \underline{8} \\ & \text { Total } 18\end{array}$

$\begin{array}{rc}\text { Rice } & 1 \\ \text { Officer } & 16 \\ \text { General } & \underline{5} \\ & \text { Total } 22\end{array}$

$\begin{array}{rc}\text { Rice } & 0 \\ \text { Officer } & 4 \\ \text { General } & \underline{18}\end{array}$

Total 22

\section{Illegitimate receiver}

\section{Criteria}

Sub category

Number of utterances

Prior knowledge of risk of danger

$\begin{array}{rc}\text { Rice } & 3 \\ \text { Officer } & 0 \\ \text { General } & \underline{0} \\ & \text { Total } 3\end{array}$

Personal responsibility for suffering

Means to address situation

$\begin{array}{rc}\text { Rice } & 8 \\ \text { Officer } & 32 \\ \text { General } & \underline{1} \\ & \text { Total } 40\end{array}$

$\begin{array}{rr}\text { Rice } & 0 \\ \text { Officer } & 3 \\ \text { General } & \underline{0}\end{array}$

No other complexities and systemic issues

$\begin{array}{rc}\text { Rice } & 0 \\ \text { Officer } & 0 \\ \text { General } & \underline{0} \\ & \text { Total 0 }\end{array}$


Table 2: Latent imagery of (il)legitimacy of giver in utterances

\section{Legitimate giver}

\section{Theme}

Sub category

Number of utterances

Personal profit not dominant motive in providing support

No personal profit Acknowledge complexity Positives of volunteerism 13

Total 32

Legitimate relationship between givers and receivers

$$
\begin{array}{rc}
\text { Professional skills } & 23 \\
\text { Time commitment } & 8 \\
\text { Legitimate orgnizations } & \underline{28} \\
& \text { Total } 59
\end{array}
$$

Receiver's long term overall benefit from the support received

Support not conditioned to advantage giver

\section{Illegitimate giver}

\section{Theme}

Sub category

Number of

Personal profit dominant motive in providing support

$\begin{array}{rc}\text { Relieve guilt/conscience } & 10 \\ \text { Voluntourists } & 40 \\ \text { Sham charities } & 11 \\ \text { Religious proselytisation } & 8 \\ \text { Students/CV } & \underline{9} \\ & \text { Total } 78\end{array}$

Limited or no legitimate relationship between givers and receivers utterances

No professional skills Not legitimate organizations 8 No time commitment

Receiver experiences negative outcomes

$$
\begin{array}{r}
\text { No long term benefit/harm } \\
\text { Disappointment } \\
\text { Induced shame } \\
\text { Relationship of dependency }
\end{array}
$$

Conditions of support advantage the giver

$$
\begin{gathered}
10 \\
2 \\
2 \\
5
\end{gathered}
$$

Total 19 